\title{
SEGERA BERGERAK SEBAGAI CARA MENYEMBUHKAN CEDERA SETELAH OPERASI SC
}

\author{
Muji Lestari' ${ }^{1}$, Fahry Amal ${ }^{1 凶}$ \\ ${ }^{1}$ Jurusan Kebidanan Poltekkes Kemenkes Jayapura
}

\section{ARTICLE INFO \\ Article history}

Submitted : 2019-06-21

Revised : 2020-05-08

Accepted : 2020-07-12

\section{Keywords:}

Sectio Caesarea

Postpartum

Early Mobilization $\triangle$ Corresponding Author:

\begin{tabular}{l}
\hline Kata Kunci: \\
Sectio Caesarea \\
Postpartum \\
Segera Bergerak
\end{tabular}

Fahry Amal

Jurusan Kebidanan Poltekkes Kemenkes Jayapura

Telp. 082198581919

Email: fachry2380@gmail.com

\begin{abstract}
One indicator of the Public Health level in a country, including Indonesia, is the Mortality Rate (MMR) and Infant Mortality Rate (IMR). Maternal death can be caused by many factors such as the labor process, especially labor by Caesarean Section (CS). Ironically, childbirth through SC is now more and more chosen compared to normal (vaginal) delivery, especially in big cities. CS childbirth, in addition to increasing the risk of death, can also be one cause of infection if treatment was in the right way. CS seams have a risk of infection during the healing process, if not handled properly and correctly will cause many problems, immediately or health problems that arise later. Immediately moving is a way to speed healing, if this is not done, it can cause an increase in body temperature due to a bad uterus so that the rest of the blood cannot be removed and causes infection. The purpose of this study was to determine the correlation of moving immediately in postpartum mothers with CS childbirth on the process of wound healing in postpartum CS. The study design was observational with a cross-sectional design. The number of patients who delivered CS in the puerperal room of Abepura General Hospital in May 2017 was the population in this study. The samples were 33 postpartum women who caesarean sections in the postpartum room of Abepura General Hospital in May 2017. The sampling technique is an accidental sampling. Data were analyzed using chi-square statistical tests. 11 respondents did not move immediately and 22 respondents who immediately moved. The results showed that there was a relationship between immediate movement and recovery rate, $\alpha=0,000<0.05$. Moving immediately is a way to heal an injury after CS surgery.

Satu penanda Level Kesehatan Masyarakat di suatu negara, termasuk Indonesia adalah Angka Kematian (AKI) dan Angka Kematian Bayi (AKB). Kematian ibu bisa disebabkan oleh banyak faktor, salah satunya adalah persalinan, khususnya persalinan dengan cara Sectio Caesarea (SC). Ironisnya persalinan dengan cara SC sekarang ini semakin banyak dipilih dibandingkan dengan persalinan normal (pervaginam), khususnya di kota-kota besar. Persalinan dengan cara SC, selain dapat meningkatkan resiko kematian juga dapat menjadi salah satu penyebab infeksi jika perawatan dilakukan secara tidak benar. Jahitan seksio caesarea memiliki risiko infeksi selama proses penyembuhan, jika tidak ditangani secara benar dan tepat akan menimbulkan banyak masalah, baik yang segera maupun masalah yang muncul kemudian. Segera bergerak adalah cara untuk mempercepat penyembuhan, jika hal ini tidak dilakukan maka dapat menyebabkan peningkatan suhu tubuh karena adanya rahim yang buruk sehingga sisa darah tidak dapat dikeluarkan dan menyebabkan infeksi. Tujuan dari penelitian ini adalah untuk mengetahui korelasi segera bergerak pada ibu post partum dengan sectio caesarea (SC) terhadap proses penyembuhan luka SC post partum. Desain penelitian adalah observasional dengan rancangan cross sectional. Pasien yang melahirkan SC di ruang nifas Rumah Sakit Umum Abepura pada Mei 2017 berjumlah 33 orang adalah populasi dalam penelitian ini. Sampel dalam penelitian ini adalah semua postpartum sectio caesar di ruang postpartum Rumah Sakit Umum Abepura pada Mei 2017 yang berjumlah 33 orang. Teknik pengambilan sampel adalah accidental sampling. Data dianalisis menggunakan uji statistik chi square. Ada 11 responden yang tidak segera bergerak dan 22 responden yang segera bergerak. Hasil penelitian menunjukkan bahwa ada hubungan antara segera bergerak dengan tingkat pemulihan, $\alpha=0,000<0,05$. Segera bergerak merupakan cara untuk menyembuhkan cedera setelah operasi SC.
\end{abstract}




\section{PENDAHULUAN}

Menurut Word Health Organization (WHO) jumlah Ibu yang melahirkan menggunakan cara sectio caesarea cukup besar yaitu sekitar $10 \%$ sampai $15 \%$ dari semua proses persalinan (WHO, 2010), Riskesdas tahun 2010 menunjukkan persentase persalinan dengan sectio caesarea di Indonesia masih besar yaitu 15,3\%, Riset Kesehatan Dasar 2013 jumlah ibu yang melahirkan dengan metode SC sebanyak $9,8 \%$.

Data RS Abepura menunjukkan jumlah pasien yang melahirkan dengan metode SC selama kurun waktu 2014 sejumlah 696 orang, tahun 2015489 orang dan tahun 2016369 orang, meskipun terjadi penurunan, tetapi jumlahnya masih cukup besar. Jumlah ibu yang melahirkan dengan metode SC cenderung meningkat setiap tahunnya. Hasil investigasi yang paling baru memperlihatkan ibu-ibu yang melahirkan dengan metode SC derajatnya melonjak hampir dua kali lipat dari tahun 2000 hingga 2015, di warsa 2000 sebesar 12 persen menjadi $21 \%$ di warsa 2015 (CNN Indonesia, 2018).

Hasil penelitian (Rahmawati, et.al, 2018) menunjukkan terdapat hubungan mobilisasi dini, hal serupa juga didapatkan oleh (Simangunsong, et.al, 2018) dan (Siagian, et.al 2019) dalam penelitian mereka. Maksud riset ini ialah memahami jalinan mobilisasi dini atas pemulihan cedera bedah cesar.

METODE PENELITIAN Jenis Penelitian
Bentuk penyelidikan adalah survei dengan rancangan potong lintang.

\section{Lokasi dan waktu penelitian}

Penyelidikan dilakukan pada RSUD Abepura Jayapura Mei 2017.

\section{Populasi dan sampel}

Komunitas penyelidikan yaitu perempuan yang bersalin dengan cara SC pada bagian nifas RS Abepura pada Bulan Mei 2017 sebanyak 33 orang, sedangkan sampelnya adalah seluruh perempuan yang bersalin dengan cara SC pada bagian nifas RS Abepura sebanyak 33 orang, metode penentuan keterwakilan adalah aksidental sampling.

\section{Pengambilan data}

Alat pengambilan informasi adalah lembar observasi terstandarisasi untuk menilai kesembuhan luka dan mobilisasi dini pada pasien SC. Peneliti melakukan observasi pada sampel dan memberikan tanda $(\sqrt{ })$ sesuai dengan hasil pengamatan.

\section{Pengerjaan serta Penjabaran Data}

Data dikerjakan memakai software SPSS ver.16, dites menggunakan Chi Square.

\section{HASIL PENELITIAN}

Hubungan segera bergerak atas penyembuhan cedera paska operasi SC diuraikan sebagai berikut:

\section{Tabel 1. Korelasi Segera Bergerak atas Tingkat Kesembuhan Cedera (Fase Inflamasi) SC pada Ruang Nifas RS Abepura}

\begin{tabular}{|c|c|c|c|c|c|c|c|}
\hline \multirow{3}{*}{ Segera bergerak } & \multicolumn{4}{|c|}{ Tingkat kesembuhan } & \multirow{2}{*}{\multicolumn{2}{|c|}{ Total }} & \multirow{2}{*}{$P$} \\
\hline & \multicolumn{2}{|c|}{ Tidak sembuh } & \multicolumn{2}{|c|}{ Sembuh } & & & \\
\hline & $\mathbf{n}$ & $\%$ & $\mathbf{n}$ & $\%$ & $\mathbf{n}$ & $\%$ & \multirow{4}{*}{0.000} \\
\hline Tidak segera bergerak & 11 & 100 & 0 & 0.0 & 11 & 100.0 & \\
\hline Segera bergerak & 1 & 4.5 & 21 & 95.4 & 22 & 100.0 & \\
\hline Jumlah & 12 & 36.3 & 21 & 63.7 & 33 & 100.0 & \\
\hline
\end{tabular}

Tabel 1 menunjukkan terdapat 11 $(100 \%)$ responden yang tidak mobilisasi dini dan juga tidak sembuh serta tidak ada $(0.0 \%)$ responden yang sembuh. Terdapat $1(4.5 \%)$ responden yang mobilisasi dini dan tidak sembuh serta $21 \quad(95.4 \%)$ responden yang melakukan mobilisasi dini dan sembuh, hasil uji statistik menunjukkan terdapat korelasi segera bergerak atas tingkat kesembuhan cedera nilai $\alpha=0.000<0.05$.

\section{PEMBAHASAN}

Tabel 1 menunjukkan terdapat 11 $(100.0 \%)$ subjek penelitian yang tidak segera 
bergerak dikarenakan masih muda dan masih mengatakan sakit pada daerah luka insisi pasca bedah, sehingga responden tersebut belum mau segera bergerak secara teratur, terdapat 21 $(95,4 \%)$ subjek penelitian yang segera bergerak secara teratur, dikarenakan responden tersebut sudah paham dan mengerti tentang mobilisasi dini, dan kebanyakan responden tersebut bukan pertama kali melahirkan melainkan melahirkan anak kedua dan ketiga.

Produk uji coba statistik memperlihatkan korelasi segera bergerak atas kesembuhan luka SC $\alpha=0.000<0.05$. Produk pengkajian tersebut sejalan dengan hasil pengkajian (Widia, 2017), dalam pengkajian tersebut didapatkan hasil bahwa setengah (55\%) subjek penelitian segera bergerak, adapun sisanya (45\%) tidak segera bergerak, temuan ini serupa produk pengkajian (Nadiya \& Mutiara, 2018) yang mendapatkan mayoritas pasien yang sembuh dari luka pasca SC adalah yang melakukan mobilisasi dini.

Mobilisasi dini dapat menjadi penyebab sembuhnya luka SC karena segera bergerak dapat menghambat arus darah tidak lancar. Arus darah yang tersumbat dapat membuat thrombosis vena dalam (deep vein trombosis) serta mengakibatkan kontaminasi. Segera bergerak adalah salah satu faktor luar selain pemeliharaan cedera. Faktor dari dalam yaitu kebiasaan makan atau corak makanan memiliki akibat terhadap kelancaran kepulihan cedera perineum (Manuaba, 2015). Hal tersebut serupa hasil pengkajian (Ditya, et.al, 2016), juga sejalan dengan hasil penelitian (Widia, 2017).

Salah satu faktor yang dapat menghambat sembuhnya luka SC adalah umur. Seseorang yang berumur $>35$ tahun biasanya akan susah untuk segera sembuh setelah operasi SC. Mayoritas responden dalam penelitian ini berumur di bawah 35 tahun, hanya ada 8 orang responden yang umurnya $>31$ tahun. Produk pengkajian (Simangunsong, et al, 2018) juga menemukan hal serupa. Produk pengkajian juga memperlihatkan subjek penelitian sebesar $67 \%$ dan hanya $33 \%$ responden yang tidak segera bergerak dan hal tersebut berkorelasi dengan kesembuhan luka. Produk penelitian tersebut sesuai dengan produk penelitian (Siagian, et al, 2019). Dalam penelitiannya (Sihombing, et.al, 2017) menemukan bahwa dari segi status kesehatan, umur $>35$ tahun merupakan salah satu faktor pendorong kejadian operasi SC pada ibu. Produk pengkajian tersebut serupa produk pengkajian (Ferinawati \& Hartati, 2019) yang mendapatkan pasien yang sembuh dari luka post SC adalah mereka yang melakukan mobilisasi dini dan responden yang melakukan itu adalah mereka yang mayoritas berumur $<35$ tahun, juga serupa produk pengkajian (Rahmawati, et.al, 2018) bahwa segera bergerak dilakukan oleh subjek penelitian berusia $20-35$ tahun.

Produk pengkajian ini serupa produk pengkajian Hartati dalam (Rahma \& Kamsatun, 2018) yang menyatakan bahwa penyebab segera bergerak adalah umur, jumlah anak yang telah dilahirkan, jenjang pendidikan, aktivitas, derajat sakit, faktor lain adalah pengalaman SC, wawasan, dorongan, dan dorongan berita. Hasil pengkajian (Mitrawati Tia, Andoko, 2015) terhadap durasi pemulihan cedera penderita yang segera bergerak menemukan hasil bahwa yang melakukan mobilisasi dini rata-rata lukanya sembuh di hari keempat, sementara yang tidak melakukan mobilisasi dini lukanya rata-rata sembuh di hari keenam.

Segera bergerak bukan saja memacu pemulihan cedera perineum melainkan mengembalikan keadaan fisik ibu jika dilakukan dengan betul dan cocok. Segera bergerak dapat mencegah arus darah tersendat. Tersendatnya arus darah bisa menyebabkan terjadinya thrombosis vena dalam (deep vein trombosis) dan mengakibatkan kontaminasi. Segera bergerak adalah salah satu faktor luar selain pemeliharaan cedera. Faktor dari dalam yaitu kebiasaan makan atau corak makanan memiliki akibat terhadap kelancaran kepulihan cedera perineum (Manuaba, 2015).

\section{KESIMPULAN DAN SARAN}

Segera bergerak merupakan cara untuk menyembuhkan cedera setelah operasi. Disarankan kepada pihak RS untuk melakukan sosialisasi yang lebih intens kepada pasien dan keluarganya tentang pentingnya melakukan mobilisasi dini.

\section{DAFTAR PUSTAKA}

CNN Indonesia. (2018). Kelahiran dengan Operasi Sesar Meningkat di Dunia. Retrieved from https://www. cnnindonesia .com/ gayahidup/20181015152 743-255-338590/ kelahiran- dengan- operasi-sesarmeningkat- di-dunia 
Ditya, W., Zahari, A., \& Afriwardi, A. (2016). Hubungan Mobilisasi Dini dengan Proses Penyembuhan Luka pada Pasien Pasca Laparatomi di Bangsal Bedah Pria dan Wanita RSUP Dr. M. Djamil Padang. Jurnal Kesehatan Andalas, 5(3), 724729. https://doi.org/ 10.25077/jka. v5i3.608

Ferinawati, \& Hartati, R. (2019). Hubungan Mobilisasi Dini Post Sectio Caesarea Dengan Penyembuhan Luka Operasi Di Rsu Avicenna Kecamatan Kota Juang Kabupaten Bireuen. Journal of Healthcare Technology and Medicine, 5(2), 318-329. https://doi.org/ 10.33143/jhtm.v5i2.477.

Manuaba, I. Bagus. Gde. (2015). Pengantar Kuliah Obtetri. Jakarta: EGC.

Mitrawati Tia, Andoko, H. D. (2015). Hubungan Mobilisasi Dini Dengan Lamanya Penyembuhan Luka Pasien. Kesehatan Holistik, 9(2), 71-75.

Nadiya, S., \& Mutiara, C. (2018). Hubungan Mobilisasi Dini Post Sectio Caesarea (SC) dengan Penyembuhan Luka Operasi di Ruang Kebidanan RSUD dr. Fauziah Kecamatan Kota Juang Kabupaten Bireuen. Journal of Healthcare Technology and Medicine, 4(2), 187. https://doi.org/10.33143/jhtm.v4i2.216

Rahma, W. F., \& Kamsatun, K. (2018). Mobilisasi Dini Ibu Post Sectio Caesarea Di Rsud Soreang. Jurnal Ilmu Dan
Teknologi Kesehatan, 5(2), 149-163. https://doi.org/10.32668/jitek.v5i2.5

Rahmawati, D., Rinda, A., \& Wahyuni, M. (2018). Hubungan Mobilisasi Dini Dengan Penyembuhan Luka Post sectio caesarea Di Rumah Sakit Umum Daerah H. Badaruddin Tanjung Tahun 2017. Dinamika Kesehatan, 9(1), 511-525.

Siagian, N. A., Nusaibah, S., \& Manalu, A. B. (2019). Hubungan Mobilisasi Dini Terhadap Penyembuhan Luka Post Operasi Sectio Cesaria. Jurnal Penelitian Keperawatan, 2(1), 14-17. Retrieved from http://ejournal. delihusada. ac.id/index.php/JPKM

Sihombing, N., Saptarini, I., Sisca, D., \& Putri, K. (2017). Determinan Persalinan Sectio Caesarea di Indonesia (Analisis Lanjut Data Riskesdas 2013). Jurnal Kesehatan Reproduksi, 8(1), 63-75. https://doi.org/ 10.22435/kespro.v8i1.6641.63-75

Simangunsong, R., Rottie, J., \& Hutauruk, M. (2018). Hubungan Mobilisasi Dini Dengan Proses Penyembuhan Luka Post Sectio Caesarea Di Rsu Gmim Pancaran Kasih Manado. Jurnal Keperawatan, 6(1).

Widia, L. (2017). Hubungan Antara Mobilisasi Dini Dengan Proses Penyembuhan Luka Rupture Perineum Pada Fase Proliferasi Ibu Post Partum. Dinamika Kesehatan, No. 1(1), 25-32. 